Kohl: a Journal for Body and Gender Research

Vol. 5, No. 1 (Spring 2019)

\title{
Yaariyan, Baithak, Gupshup: Queer Feminist Formations and the Global South
}

\author{
Naveen Minai and Sara Shroff
}

\begin{abstract}
:
In this essay, we join Linda Tuhiwai Smith's (1999) and Eve Tuck's (2009) call to decolonize and de-center "damage-centered" research, embedded in settler/colonial ways of knowing. We attend to the ethical responsibility and intimate relationalities that this contemporary moment requires of us as privileged feminist, queer, global south, and South Asian scholars. We introduce yaariyan, baithak, and gupshup to theorize queer feminist care in/as research practices. As ethics of care, compassion, and collectivity, these practices enable us to study and share knowledges together. Building on transnational feminist and queer scholarship (Chowdhury and Philipose 2016; Banerjea et al. 2017), we argue that responsible knowledges mean thinking about methods as relational rather than transactional and relationality as activated and not automatic. We explore how gupshup and baithak provide methodologies of co-production of knowledge, inclusion, accountability, sharing, and reflection. This work must be located in different frameworks of home, diaspora, and language. Pakistan, we contend, is always already a transnational space in which gender and sexuality have been categorized (to deadly consequences) but not contained as words which denote experiences, identities, practices, desires, and histories. It is these words that we reach for in and through our friendship as a condition of possibility of a different kind of knowledge-making.
\end{abstract}


How should a Brooklyn-based, Karachi-born desi queer feminist scholar (Sara) work with feminist, queer, and trans activist communities in Pakistan? How do queer, trans, and feminist theories travel? How do we theorize for and with our communities rather than on and about them? Furthermore, how should a Karachibased, Los Angeles-educated desi queer feminist scholar (Naveen) construct "desi butch" as sexual-spatial analytic? How does desi and butch form, transform, translate, untranslate on the pages next to queer, trans, lesbian, bisexual, khwajasira (master of secrets, also name for a subsection of Pakistani trans communities), moraat (man and woman), and zenana (of women, feminine soul)? How does our social and economic class privilege certain masculinities, femininities, and sexualities while erasing and endangering others in our work?

In addressing the questions above, this essay follows in the tradition of Linda Tuhiwai Smith's (1999) and Eve Tuck's (2009) call to decolonize and de-center "damage-centered" research. Tuhiwai Smith and Tuck teach us that colonial ways of knowing are devoid of care practices, compassion, and accountability circuits. They challenge us to re-center desires in all their hauntings, pleasures, conflicts, healing, living, and hopes. They push us to make worlds by not reducing ourselves and our communities as sites of brokenness, damage, data, pain, and ancestral trauma alone. In answering their call, we also center what José Esteban Muñoz (1999) teaches us - that care labor is the precondition for knowledge-making, and to reject research practices that extract, control, discount, categorize, compete, and colonize. In this essay, we attend to the ethical responsibilities and intimate relationalities that this contemporary moment requires of us. We study gender and sexuality politics in and from Pakistan as junior feminist, queer, and South Asian scholars with social and economic capital, situated between the global north and global south.

We introduce yaariyan (friendship), gupshup (a mode of speaking), and baithak (a mode of space) to theorize our queer feminist care as research practices. We use these practices to hold each other accountable and to reorient our research questions, frameworks, and genealogies. We use them to challenge the networks of authority that demand we make gender and sexuality in and from the global south knowable, legible, and visible only on certain terms. We mark Pakistan as a site for theorizing and worldmaking instead of just a site of fieldwork. Ultimately, we are asking the difficult questions of what decolonial means in Pakistan. So while we focus on our yaariyan as a mode of survival, pleasure, and accountability, it also serves as the means through which we find and engage our interlocutors in responsible and respectful ways. Our goal is to think with rather than for, to interrogate our assumptions of authenticity and authority, and to expose the multiple and different forms of power within processes of knowledge production.

In taking up the inherent messiness through which decolonial knowledges about gender and sexuality become possible, we interrogate what we have been taught as appropriate and authentic knowledges, pure methods, and proper and productive ways of being feminist, queer, global south, South Asian, and scholars of color (Grewal and Kaplan 1994; Collins 2000; Sandoval 2000; Santos 2014). We argue here that yaariyan, gupshup, and baithak compel us to think through the purpose of our knowledge production. We are learning that we must be attentive to, and wary of, what we call automatic belonging. We define this as the notion of belonging deployed as ownership that functions through particular globalized logics of race, ethnicity, and language. For example, just because our passport/ID states "Pakistani" does not mean that we belong in and to the different ethnic, linguistic, class, and sexual communities in Pakistan in ways that authorize us to speak 
for those communities. Second, just because we are brown and South Asian that does not mean we adhere to the straight or straightened disciplinary borders in South Asian, Pakistani, and/or postcolonial studies. Automatic belonging can be dangerous when the logics of belonging are operationalized in ways that produce access as entitlement, and when the politics of authenticity function as politics of authority. In this way, yaariyan, baithak, and gupshup enable us to account for what these logics erase, or what Muñoz calls (1999) labor, the work, the awareness that it takes to belong, where "belong" means an orientation of care. We theorize gupshups and baithaks as counter spaces and side-conversation in homes, courtyards, corners, benches, balconies, dinner tables, gardens, sidewalks, footpaths, Facebook messages, late nights, early mornings, and quiet afternoons. These are not necessarily and always on the margins; sometimes, we and our interlocutors hold gupshups and baithaks in centers of power.

We are each situated in the American and Pakistani academies as junior scholars who have considerable social and economic capital due to our backgrounds. Naveen is an assistant professor at a private/public institute in Karachi, while Sara is completing her PhD in public policy, and works as an adjunct in New York City. Situated within these privatized logics, we write with and against the limitations of multiple and global neoliberal academic institutions and networks (Ferguson 2012; Chatterjee and Maira 2014; Bhambra et al. 2018). We take up sexuality as a key analytic in our work. Naveen's doctoral dissertation, "Too Muchness: Un/totalizing Pakistani National Narratives of Crisis," examined queerness as excess that emerges in moments of historical crises of postcolonial nationalism because of the contradictions of sexuality, class, and affect that underpin dominant Pakistani masculinities. Similarly, Sara's upcoming dissertation, "Valuefacturing Life: Capital Encounters and Trans/Feminist Becomings in Pakistan and Beyond," takes up the genealogies of sexuality, race, and capital, in contemporary Pakistan through three figures: modern and modest Muslim woman, the corporate/liberal feminist, and the transgender citizen.

In our newer work, we explore female masculinities, lesbian sexualities, and global south trans/feminist activism as sites to rework and rethink concepts of home, land, language, diaspora, resistance, and belonging. Among other things, we focus on multiple ways in which different colonialisms mutate, move, nest, and coalesce in and across different contexts (Driskill 2010; Walia; 2013; Khusro, 2019, Bacchetta et. Al 2019, Da Costa et. Al 2019). To us, this means analyzing not only the globalized logics of whiteness, but also how integrated categories of race, ethnicity, nationality, gender, class, and sexuality travel in circuits and networks between the U.S. and Pakistan, troubling binaries of urban and rural, metropole and periphery, national and transnational. For example, what does it mean for us to account for Sara and Naveen's presence on settler colonized lands in the U.S. and where do we locate ourselves in relation to Indigenous Nations and Black communities? What does it mean for us to speak Urdu and English in Pakistan where both are languages of privilege and power but also of resistance, class aspiration, and mobility? And what does it mean when they exist in tension with other local/regional languages such as Pashtun, Persian, Sindhi, Balochi, Seraiki, Bengali, Gujarati, Memoni, and Punjabi, among others?

To borrow from Sadia Abbas, the global south is seen as a tabula rasa where you can experiment and empiricize - but never theorize (Abbas 2010). As one such site, Pakistan is often marked as a space where gender and sexuality (as categories, as nomenclatures, as theories, as frames) must be introduced, invented, 
and curated. This is not just about whiteness. This is also about the ways in which racial, gender, and class privilege travels between global north and global south: white saviors, brown saviors. We argue here that the queer, feminist, and trans communities in the global south need neither. We challenge the conditions under which global south knowledges "arrive" in academia as archivable and absolute truths by asking: what are our responsibilities and to whom? What does it mean to put Black queer and feminist epistemologies next to epistemologies deployed by feminist, queer, and trans communities in Pakistan to navigate and negotiate state violence? How do we start to read across different frames to disrupt dominant interpretations of gender, sexuality, Pakistan, South Asia, and global south? What does queer and feminist mean in Pakistan and what do these meanings tell us about colonial legacies, neo-imperialisms, and global/racial capital? To follow Elora Chowdhury and Liz Philipose (2016), how do we learn from our dissident friendships that work across multiple borders and multi-scalar violence?

By centering yaariyan, baithak, and gupshup as affective, conditional, and communal practices, we are able to offer knowledges - less as a lone, or lonely, and linear project, and more as a relational and reflexive playful feminist practice (Anzaldúa et al. 1983; Lugones 1987; Sandoval 2000; Harney and Moten 2004; Chowdhury and Philipose 2016; Banerjea et al., 2017). We ask: what are the conditions in which we are producing and reproducing knowledges? Which processes do we deploy and, in turn, which processes do we disassemble or disaggregate? What are the consequences of producing knowledges where knowledge as practice becomes knowable product? Who do these theories serve and make successful and who do they un/shelter and make vulnerable? In asking these messy, difficult, yet urgent questions, we challenge our disciplinary/disciplining training where doing and knowing constitute done, defended, and known, and where knowledge is power. We return to the plural and the politics of privilege.

The paper proceeds in three sections. First, we discuss yaariyan as feminist lifelines that enable us as queer feminist scholars of color located in/between academic institutions/networks in the global north and global south to produce and circulate knowledges. Next, we theorize baithak and gupshup as methodologies and as methodological ethics that hold possibilities for different forms, frames, feelings, and circuits of knowledges. We close with sharing why our yaariyan, baithak, and gupshup offer the potential to answer Tuhiwai Smith's call to open "possibilities that can only be imagined as other things fall into place" (Smith 1999: xii).

\section{Yaariyan: Feminist Lifelines}

Yaar is an informal, affectionate, and pejorative term in South Asian languages that refers to a close friend, lover, companion, or a temporary intimate name for an otherwise stranger. It often denotes friendships that are platonic, romantic, and temporal, mainly between men, or erotic/ disrespectable friendships (but not always) between men and women. The term is often seen as unbecoming of a respectable woman in South Asian middle class/elite circles. The preferred term in Urdu is saheli for female friendship and dost for friends in general. Yet, these words do not reflect the erotics (Lorde 2007) connoted by term yaar (friend) and frame yaariyan (friendship), which we are trying to take up as sites of non-normative feminist queer friendships. 
Rooted in this definition and our lived experiences, we theorize yaariyan as a conditional state of intimacies and affective attachments. Unlike the myth of (white) feminist sisterhood (Lorde 2007; Kendall 2013; Ahmed and Fitzgerald, 2017), yaariyan is neither unconditional nor devoid of contention and complexities. White feminists have consistently dismissed and devalued the contributions and concerns of women of color from feminist spaces, conversations, and movements, labeling calls for accountability and intersectional analyses divisive to feminist friendships. We find yaariyan compelling because it expands our frame of existing structures of care: biology, nuclear family, formality, and even certain friendships that rely on sameness, equality, fairness, and compliance. As yaars, we come to yaariyan with different starting points, access, and abilities, different skill sets, different worldviews, and different spatialities (Lugones and Rosezelle 1995). Yaariyan is important for women, queer, trans people, working-class, and poor communities of color, to survive in and move through globalized academic institutions.

Yaariyan constructs space to gather up knowledges that have been ubiquitous yet undermined by global north theorizations and teleologies. It is a space of refuge and resistance - being together and building where we work through our desires, vulnerabilities, ruptures, belongings, and openings. They manifest through loving glances, mutual projects, edited scripts, unstoppable laughter, old and new curse words, collective reparative rage, melancholia and unnameable desires, and the everyday poetics across time zones and zip codes.

Sara Ahmed writes that transnational feminism is work "across national boundaries; but we also work together on those boundaries, since their very existence means some of us cannot turn up" (Ahmed and Fitzgerald 2017). As feminist, queer, and women of color scholars within some vectors of privilege, outside others, living on the borderlands of Pakistan and the U.S. and soon Canada, we are constantly "working on where we are; working where we are, which is working with and working under restriction" (Ibid.). Our yaariyan is work that is attentive to knowledge as a continuous process of collective consciousness. For us, knowledge-making is always-already a knotty transnational process; it forces us to take up the politics of privilege and our situated solidarities by coding them in value, capital, shared and splintered histories, laboring bodies, and our shared struggles.

Yaariyan allows us to pay close attention to the pre-production phases, the behind the scenes, and that which lives in between the lines of our ongoing laboring: unfinished thoughts and finessed projects. It allows us to move through the cracks of our academic disciplines and in/formal networks in/of the academy together as co-conspirators and co-informers. We challenge each other's frameworks, perspectives, citations, methods, and disciplinary conclusions. Through recommended readings, photocopied books, shared bibliographies, conference panels, co-authored essays, and conversations about connections between texts and theories, we loiter together between disciplines and fields. Our yaariyan provides us both with a method and space for resisting and negotiating the isolation and hierarchies instituted and reinforced by globalized academies, reinforced over again by national borders. 
To dismantle tools of hegemonic theories (Lorde 2007), we do each other's work, we cite each other to give thanks and acknowledge indebtedness of our labor. We write together in shareable documents, revising and rewriting each other's sentences. Our intimacies are located in the different color codes as we create conversation on the page, the comments we leave for one another, and the copious notes while talking on Facebook, WhatsApp, or FaceTime. In getting to know how each thinks, we start to hear each other in our sentences, in words, phrases, punctuation, style, and theoretical stances that we share. Our yaariyan as method includes the work that goes into reaching for each other across time zones of the U.S. and Pakistan, which includes waking up and staying awake across and in the 10 hours between us. These critical intimacies enable us to be where we are, do the work that we do, and sustain each other through the globalized systems of exploitation in institutionalized academies.

We are in conversation with our interlocutors as our yaars, rather than our informants. Their laughter, anger, pain, and sarcasm at the fragility of neoliberal and neocolonial university structures, and the absurdity of politics of purity and authenticity, hold us accountable. Our yaariyan are located in between circuits of spaces and conversations in and across continents, anchoring us in and to what Adrienne Rich (1994) calls a politics of location and enabling us to be attentive to the disciplinary effects of area studies as reinscriptions of bounded loyalties. These bounded loyalties of both state and discipline are settler colonial and colonial effects and mechanisms. Our yaariyan, therefore, enables us to detect them as we come up against them together, and challenge the binaries of West/East, Western/non-Western, object/subject, and Pakistan/diaspora. As yaars, we center and illuminate the relations of power that we are all embedded in, including the politics of class, religion, and citizenship. For example, who pays for the time that our interlocutors spend with us in upper class cafes? What does meeting up for "coffee" versus "chai" denote? Who has to negotiate visa applications and who has the privilege of being out? We want to make clear that our yaariyan does not enable us to resolve these questions, but rather to state them clearly, start to address them, and be constantly reflexive of dynamics of power between us and the communities that we are part of and that we make a claim to be studying with. Who is studying with whom? Who is being credited for that work? How do we think about the materiality of care in yaariyan as a mode of reciprocity rather than transaction in which knowledge is extracted as data, transformed into product through publication, and deployed as intellectual and social capital in exclusive spaces?

Feminist friendships are also important frames within which we hold each other accountable as a form of love and care, which are method, mode, and process. The love that orients us towards each other is based on mutual labor, not productivity, use value, or perfection. This mutuality is about learning difficult lessons in the process of recognition, creation, reinforcement, and maintenance of complex relations between and across ourselves and the multiple worlds in which we exist. This accountability is a feminist and queer way of living together precisely because accountability as love is based on the recognition of difference in experience, location, trauma, healing, and desire. Accountability and difference both are coordinates of an orientation and alignment within the space and frame of our feminist friendships. They are about a practice of compassion through our relations with each other, rather than an awareness that begins with, and centers, an autonomous self. Feminist friendships, then, are a relationality, a method of and for becoming ourselves, and a way of being in the world. 
Our selves are often marked as feminist killjoys (Ahmed 2010). But we are joyful in our yaariyan. In reaching for joy, we make space, make time, make languages, make mistakes, make lessons. We make knowledge, and this process is alive as a form of collective consciousness, as a form of intimacy, as a form of trust, as a form of pleasure, as a form of joy. We laugh at the density of a text we are trying to understand, we joke about the untranslatability of words, we grin at bad puns and clever titles. Pleasure is how we catch our breath; pleasure is how we articulate our vulnerabilities in languages "respectable" young desi women/serious scholars of color should not use.

While friendship is not a mode exclusive to desi women, and desi queer and trans communities, the word yaar does the work of attending to the specificities of desi experience, and the contradictory and conflicted relationships we each and together have with South Asia as a place of pain, anger, endurance, and intimate estrangements. It is through our feminist queer friendship as desis that we know how complicated the word belonging is and what it does to each of our bodies. There is pleasure in being able to look at each other or sigh together or not complete a sentence or roll our eyes and know. Through our yaariyan, we understand what the incomplete, unspoken gestures of our bodies mean. These gestures speak to the darkness of everyday survival; they are affective embodiments in that they are composed of multiple feelings that we are not always able to transform into words, but articulate instead with our bodily gestures (Sedgwick 2003).

\section{Gupshup and Baithak: Intimate Informalities}

Ways of speaking become crucial to how we experience and encounter space and place. How we speak (gupshup) is rooted in where we speak (baithak). In this section, we explore the intricate relationship between ways of speaking and ways of gathering. The following questions guide this section: what does it mean for Naveen and Sara as feminist and queer scholars of color to sit and talk with each other, to make space for each other in sometimes hostile places dominated by whiteness? How do we sit with feminist, queer, and trans activists, some of whom are also academics but do not have the same social capital as us? How should the power differential be acknowledged and negotiated? How do we speak and sit together in dominant spaces that claim to be organized for us but not by us? Where do we feel comfortable enough to sprawl and stretch and how does this intimacy, informality, comfort, and safety affect the process of knowledge-making? Should some knowledges about/of gender and sexuality in/of/from the global south remain in the forms that we (and the question always arises: who is "we?") find and experience them? Are these knowledges ours to share, to transcribe, to publish? To sprawl next to someone in an intimate, informal space is a specific relation between us: we understand that everything we say will not be transcribed and translated, hence transformed into public knowledge - that is the trust and safety that underpins our gupshup and baithak.

Gupshup in South Asian languages means casual conversation, colloquial discourse, informal dialogue, oral exchange of feelings, observations, and ideas. It is spontaneous and unscripted, but only accessible when an intimacy is in place, or where and when intimacies and informalities are present - that is, yaariyan. In this way, gupshup includes everyday practices we all engage in, such as chit-chat, gossip, cursing, playful 
scolding, and prattling. Gupshup allows us to loiter with languages, laugh at linear thinking, and wander in and out each other's worlds as we sit in our intimate and informal worlds. We are reminded of Gloria Anzaldúa (1987) who asserts that "wild tongues can't be tamed, they can only be cut out" (54) and equates the taming of tongues to "linguistic terrorism" (38). While Anzaldúa is writing at the Mexican/U.S. border, she advises us to resurrect our languages and linguistic proclivities and pluralities that shift across class, caste, race, ethnicity, gender, sexuality, land, and nation. It is through gupshup that we cut through the rules of speech about gender and sexuality in/from the global south, especially in institutionalized academic spaces. These rules demand a performance of authenticity, a straight-as-linear account of indigeneity, a frame that fixes languages in time and place. Yet, at a recent academic conference on gender and sexuality in Pakistan, the term naan binary was invented and shared when conference participants (activists, academics, and artists) were trying to talk about the politics of translation of gender non-conforming bodies and practices between languages. Naan, a type of bread in South Asia, contends and refuses the absurdity of the demand to make ourselves legible and ascribable according to a particular politics of purity and authenticity of language. Instead, naan binary opens up space to play with different languages, to understand language and translation as always-already matters of multiplicity and mixture, and to think with care of what different words in different languages mean to each of us.

We claim instead the vastness of the languages we know, the ones we are learning, the ones we have forgotten and are remembering, the ones we have adapted, and the ones that we are still adapting. We claim home in many languages and on many lands while we navigate uneven citizenship statuses as alien, non/resident, undocumented, settler, and mohajir (Muslim immigrants to Pakistan from India, often known as Urdu-speaking), PhD students, adjunct/part-time faculty, and assistant professor.

Gupshup, in multiple and half languages, enables us to reach for knowledges in different vocabularies, accents, and epistemologies by allowing us to listen to articulations of gender and sexuality as relations of power, form, and difference. We may not be able to speak and hear these words if we insist on respectability, purity, singularity, and authenticity within dominant frames and boundaries of modern nation-states, colonial legacies, and settler colonial formations. Gupshup is what happens outside formal academic conference rooms, allowing for a refusal and reworking of hierarchies of speech: student/professor, junior scholar/full professor, global south/global north. It is a talking within and talking among that allows us to talk back to power, challenging the ways in which we are spoken over, spoken to, and spoken at. Gupshup demands a reworking of the desi imperative to defer in two ways. First, it challenges the entitlement to obedience embedded in the relations between researcher and communities, and between junior and senior scholars. Second, it allows us to speak sideways to what is not canon, to what is made unavailable to us because of the intellectual lines that point us to towards some scholarship and away from others (Ahmed 2006). Gupshup is an articulation, then, of resistances to the imperatives of discipline (and punish) of academic authorities that travel across state borders, to singular authorship as singular authorization, to straightened spatial genealogies and intellectual genealogies.

It is through gupshup that we untame our feral tongues to think and do theory. Speaking is always-already a translation from thoughts to terms, and from feelings to languages, formulations, and utterances. Anzaldúa 
advises us to re/construct new, secret languages that cut across words, forms, and disorders, so that queering language becomes a mode of creating knowledges: naan binary is a play on non and naan, recognizable to desi queer and trans communities and indicating the complications of grammar, syntax, class, languages, and desi as categories that move across South Asia.

As intimate relationalities, gupshup is hardly new. Women and communities of color have always spoken in codes, switching from everyday vernaculars to a "white voice" to survive in the sea of whiteness (hooks 1992; Ahmed and Fitzgerald 2017). We are often told in the academy - especially for theoretical papers and academic talks - to be more direct, state our claim upfront, situate the problem, organize our thoughts, provide evidence, clarify our contributions, and end with a conclusion. Over the years, we have become good at writing and speaking in academese; we too have trained and twisted our tongues to survive. We too have been experts in code-switching. It is precisely these gupshup sessions - these self-care spaces necessary for play, pain, and pleasure - that do the work of decolonizing knowledges and dismantling vocabularies.

Baithak means "seat," "a place to sit," the act of sitting, and/or the state of being seated. It often indicates friends sitting together, and an invitation for people to visit for an intimate, informal gathering. Baithak, in popular understanding, connotes sitting on the floor. You can only sit on the floor in some rooms; to do so in others is a breach of protocol and propriety determined by age, gender, class, and the purposes of different spaces. Our bodies are positioned and aligned differently when we sit on the floor: they can sprawl, stretch, and slump. Our bodily claims on and in that space change and so do our orientations towards each other. In other words, we slump, stretch, and sprawl with those with whom we are intimate because our bodies have sunk comfortably into that space as a collective space. Baithak, then, can be theorized as a spatial relation that starts collectively. To invite people to a baithak is an invitation to share space and to be in a space together.

Baithak is about invitation; we invite those with whom we are or have chosen to be intimate and informal. As a space where we sit with each other, it therefore is a methodology rooted in a space and made collective against the rules that govern the demarcations of space and belonging. The digital and live baithaks in bedrooms, Google docs, kitchens, balconies, co-produced panels, workshops, Facebook messenger, WhatsApp groups, and cafes allow us to sit in spaces between these borders and boundaries to produce knowledges. As a methodological practice, baithaks challenge the hierarchies between disciplines, academies, states, and regions precisely because we sit together in spaces between.

We do not claim that baithak undoes relations of power. In fact, the term baithak is also being deployed as a term for neoliberal community engagement by philanthropic interventions in Pakistan too. Therefore, our goal is to think about baithak critically as both an act and a space that can only be activated once we have created relationships that acknowledge the differentials of power, experiencing them openly and honestly and not as lip service to community engagement. For example, baithak is when Naveen, as an assistant professor in Pakistan, asks queer/trans students what they would want from queer/trans spaces while sitting next to those students on the stairs: this spatial positioning outside the classroom does not undo the differentials of power between professor and student. It enables instead an acknowledgement of who can, and is, sitting next to 
whom and how. In other words, you cannot sink into space together in a baithak if you do not have trust and accountability. It requires that those with privilege account for themselves to those who are vulnerable and marginalized in different spaces. To be able to organize and invite a baithak means, then, that the works of solidarity and accountability have been done, and are ongoing. Naveen and Sara's informalities and intimacies are possible because we work on and through the differences between us. These are part of how we navigate and negotiate institutional networks and spaces together and for each other. This includes recommending each other's work to other scholars, inviting one another to speak at panels and conferences, discussing employment opportunities and applications, and alerting one another to the institutional/institutionalized politics of different academies.

We offer baithak as collective ethics: if Naveen and Sara are not invited to participate in a baithak within and by a particular community, then perhaps that should serve as a mode and moment of accountability of why and how we have not been invited. Simultaneously, we need to think about what responsibility we each have when invited and how our presence affects the politics of space. Based on invitation, baithak offers a way of thinking about the production of knowledge that is built on responsibility and trust earned by scholars of, next to, and within vulnerable communities. For example, at the same aforementioned academic conference on gender and sexuality in Pakistan, Naveen and Sara were both presenters, yet important community voices were absent. As queer is taken up in different ways in academic spaces in Pakistan, scholars like us cannot do so without acknowledging the labor of everyday activism by community organizers and activists, some of whom are also academics. This imperative to pause and reflect, to be alert to matters of trust and intimacy, to be mindful of being invited into a shared space and of who is invited by whom, and the form these invitations take is part of how baithak as method is underpinned by empathy and responsibility.

Baithak and gupshup are necessary research ethics to work with queer and trans communities in the global south who are vulnerable along multiple axes of identity and structures - ethnicity, nation, religion, and class. These communities rely on networks of trust and intimacy for both protection and survival. Their experiences, histories, vocabularies, and labors are often extracted by scholars who are not part of the baithaks of these communities and who do not share their research as and through gupshup with them. Moreover, baithak and gupshup are continuous and do not end with a publication or a conference. As scholars, we must return to the communities to which we are accountable.

Baithak and gupshup enable us to also ask whether all knowledges of/between queer and trans communities in/from the global south should be transcribed and circulated outside those communities at all, and by whom. Everything said in a baithak or as part of gupshup cannot be translated and transcribed from one language to another, from one form to another, from one space to another. Scholars invited to gupshup during a baithak must be alert to how some knowledges should not be dislocated from these spaces, moments, and tongues. This is not only about the informalities and intimacies between Naveen and Sara as co-thinkers and cowriters. These are also the ethics built into baithak as a space-based methodology and gupshup as a framework for the politics of language, translation, resistance, and rage. 


\section{Feminist and Decolonial Research Care Practices}

Yaariyan, baithak, and gupshup are queer feminist research care practices that attend to subjugated knowledges, silences, solidarities, and strategic ways of naming and navigating global south knowledges on sex/gender/sexualities. As we have shown, our ways of studying and thus scholarship are not disconnected, detachable, or divisible - we are the scholar, the subject, and the study materials. In hegemonic scholarship, we become the statuette body that is being researched as non-feeling/non-human object and as objectified representation of diverse communities, histories, desires, cultures, and contexts. In this way, our queer feminist research care practices are as much about who we are as scholars and the ways we are "producing" as about knowledge itself.

Alexander Weheliye (2014) argues that we must contend with the settler/colonial and neocolonial nature of the relationship between the global south and global north; the former is the site of extraction for the latter, producing knowledge through dehumanizing evidence. Indigenous scholars and feminist/queer/trans scholars of color have demonstrated how Foucault's history of sexuality is the history of sexuality of nationstates in Europe and North America, in which transnational colonialism, slavery, and settler colonialism have been conspicuously, deliberately, and methodologically erased (Gunn Allen 1986; McClintock 1995; Puar and Rai 2002; Stoler 2006 and 2009; Miranda 2010; Rifkin 2010; Morgensen 2011; Ferguson 2012; Snorton 2017).

By centering feminist friendships, we acknowledge our different locations and experiences in academic institutions and circuits, and the complexities of our individual and collective privileges. Baithak and gupshup are the modes through which we do this labor of love for each other as yaars, and it is our yaariyan that allows us to move across these frames, fields, and fragments. They signal trust, intimacy, and informality as logics to making knowledge about gender and sexuality in/from the global south in a way that does not conform to dominant forms and networks, especially institutionalized and individualized ones.

Yaariyan, gupshup, and baithak are temporal and spatial relational experiences. They are the underbelly of our writing - the messy, real, painful, ancestral, erotic, affective, archival, bodied, and spoken/oral work before we present our formal selves. They are also the work behind the writings, the people behind the baithaks, the scribbles through our gupshup, the fragments before the finished product. Thinking in these ways allows us to grapple with knowledges as always intimate, collective, painful, incomplete, playful, and possible. Through our yaariyan, we desire and demand care for each other and our communities across the global South, shift the ways we care and love, and use the labor we do for ourselves, keeping in mind the possible future for the other. Our ways of knowing carry, curate, and change us as we change, construct, and carry them.

We see our knowledges and those we are making knowledges with as the labor and love of our existences, experiences, and experimental ways of theory-making. We understand decolonization as the necessary reckoning with the coloniality of our ethics, epistemes, and ways of living. Decolonization requires centering counter-hegemonic systems of thought that are always-already connected to living, healing, aesthetics, and 
42 many ways of worldmaking. Thus, we reach for our yaariyan to teach and grant us tools that compel us to theorize interconnectivities despite and against colonial categorizations. It is therefore within and between these baithaks and gupshups that we embrace our pluralities, are able to present our many ways of moving across methods, and propose the "l" as an us, and each other as "yaars." 
Abbas, Sadia. 2010. "Itineraries of Conversion: Judaic Paths to a Muslim Pakistan." Beyond Crisis: Reevaluating Pakistan. Edited by Naveeda Khan. London, New York, New Delhi: Routledge.

Ahmed, Sara. 2006. Queer Phenomenology: Orientations, Objects, Others. Durham and London: Duke University Press.

Ahmed, Sara. 2010. The Promise of Happiness. Durham and London: Duke University Press.

Ahmed, Sara, and Fitzgerald, Adam. 2017. "Sara Ahmed: Once we Find Each Other, So Much Else Becomes Possible." LitHub, April 10, 2017. https://lithub.com/sara-ahmed-once-we-find-each-other-so-muchelse-becomes-possible/

Anzaldúa, Gloria, Moraga, Cherríe, and Bambara, Toni Cade. 1983. This Bridge Called My Back: Writings by Radical Women of Color. Kitchen Table/Women of Color Press.

Anzaldúa, Gloria. 1987. Borderlands/La Frontera: The New Mestiza. San Francisco: Spinsters/Aunt Lute Books.

Bacchetta, Paola, Maira, Sunaina, and Winant, Howard. 2019. Global Raciality: Empire, Postcoloniality, Decoloniality. New York: Routledge.

Banerjea, Niharika, Dasgupta, Debanuj, Dasgupta, Rohit K., and Grant, Jaime M. 2017. Friendship as Social Justice Activism: Critical Solidarities in a Global Perspective. Chicago: University of Chicago Press.

Bhambra, Gurminder K., Nisancioglu, Kerem, and Gebrial, Dalia. 2018. Decolonising The University. London: Pluto Press.

Chatterjee, Piya, and Maira, Sunaina. 2014. The Imperial University: Academic Repression and Scholarly Dissent. Minneapolis: University of Minnesota Press.

Chowdhury, Elora H., and Philipose, Liz. 2016. Dissident Friendships: Feminism, Imperialism, and Transnational Solidarity. Chicago and Springfield: University of Illinois Press.

Collins, Patricia Hill. 2000. Black Feminist Thought: Knowledge, Consciousness, and the Politics of Empowerment. New York: Routledge.

Da Costa, Dia, and Da Costa, Alexandre E. 2019. "Introduction: Cultural Production Under Multiple Colonialisms." Cultural Studies. DOI: 10.1080/09502386.2019.1590436.

Driskill, Qwo-Li. 2010. "Doubleweaving Two-Spirit Critiques: Building Alliances between Native and Queer Studies." GLQ: A Journal of Lesbian and Gay Studies. Vol. 16, No. 1-2: 69-92. Project MUSE. http://muse.jhu.edu/article/372445

Ferguson, Roderick A. 2012. The Reorder of Things: The University and Its Pedagogies of Minority Difference. Minneapolis: University of Minnesota Press.

Grewal, Inderpal, and Kaplan, Caren. 1994. Scattered Hegemonies: Postmodernity and Transnational Feminist Practices. Minneapolis: University of Minnesota Press.

Gunn Allen, Paula. 1986. The Sacred Hoop: Recovering the Feminine in American Indian Traditions. Boston: Beacon Press.

Harney, Stefano, and Moten, Fred. 2004. "The University and the Undercommons: Seven Theses." Social Text. Vol. 22, No. 2: 101-115. Project MUSE. https://muse.jhu.edu/article/55785.

hooks, bell. 1992. Black Looks: Race and Representation. Boston: South End Press. 
Kendall, Mikki. 2013. "\#SolidaritylsForWhiteWomen: women of color's issue with digital feminism." The Guardian, August

14, 2013. https://www.theguardian.com/commentisfree/2013/aug/14/solidarityisforwhitewomen-hashtagfeminism

Khusro, Amira. 2019. Personal communication.

Lorde, Audre. 2007. Sister Outsider: Essays and Speeches. New York: Crossing Press.

Lugones, Maria C. 1987. "Playfulness, 'World'-Travelling, and Loving Perception." Hypatia: A Journal of Feminist Philosophy. Vol. 2, No. 2: 3-19. https://doi.org/10.1111/j.1527-2001.1987.tb01062.x.

Lugones, Maria C., and Rosezelle, Pat Alake. 1995. "Sisterhood and Friendship as Feminist Models." Feminism and Community. Edited by Penny Weiss. Temple University Press. 135-145.

McClintock, Anne. 1995. Imperial Leather: Race, Gender and Sexuality in the Colonial Contest. New York and London: Routledge.

Miranda, Deborah. 2010. "Extermination of the Joyas: Gendercide in Spanish California." GLQ: A Journal of Lesbian and Gay Studies. Vol. 161, No. 2: 253-284. DOI: 10.1215/10642684-2009-022.

Morgensen, Scott Lauria. 2011. Spaces between Us: Queer Settler Colonialism and Indigenous Decolonization. Minneapolis: University of Minnesota Press.

Puar, Jasbir, and Rai, Amit. 2002. "Monster, Terrorist, Fag: The War on Terrorism and the Production of Docile Patriots." Social Text. Vol. 20, No. 3: 117-148. JSTOR. http://www.jstor.org/stable/40283318.

Rich, Adrienne. 1994. Blood, Bread, Poetry: Selected Prose 1979 - 1985. W. W. Norton \& Company.

Rifkin, Mark. 2010. When Did Indians Become Straight?: Kinship, the History of Sexuality, and Native Sovereignty. Oxford: Oxford University Press.

Sandoval, Chela. 2000. Methodology of the Oppressed. Minneapolis: University of Minnesota Press.

Santos, Boaventura de Sousa. 2014. Epistemologies of the South: Justice Against Epistemicide. Boulder: Paradigm Publishers.

Sedgwick, Eve. 2003. Touching Feeling: Affect, Pedagogy, Performativity. Durham: Duke University Press.

Smith, Linda Tuhiwai. 1999. Decolonizing Methodologies: Research and Indigenous Peoples. 1st Edition. London: Zed Books.

Snorton, C. Riley. 2017. Black on Both Sides: A Racial History of Trans Identity. Minneapolis: University of Minnesota Press.

Stoler, Ann Laura. 2006. Haunted by Empire: Geographies of Intimacy in North American History. Durham and London: Duke University Press.

Stoler, Ann Laura. 2009. Along the Archival Grain: Epistemic Anxieties and Colonial Common Sense. Princeton: Princeton University Press.

Tuck, Eve. 2009. "Suspending Damage: A Letter to Communities." Harvard Educational Review. Vol. 79, No. 3: 409-428. https://doi.org/10.17763/haer.79.3.n0016675661t3n15.

Walia, Harsha. 2013. Undoing Border Imperialism. Chico, California: AK Press.

Weheliye, Alexander G. 2014. Habeas Viscus: Racializing Assemblages, Biopolitics, and Black Feminist Theories of the Human. Durham and London: Duke University Press. 